\title{
Socialization as a New Challenge in Current Conditions
}

\author{
Y. P. Gumeniuk, O. O. Gumeniuk, O. Y. Huhul, L. B. Kolinets, O. Tsokol
}

\begin{abstract}
In the article the process of socialization as a new challenge in current conditions has been studied. It has been proved that social development plays the key role in the measures of the century we are living at. The evolution of the attitude to socialization among the scholars has been considered. The importance of developing social partnership mechanisms in the conditions of the current reality has been shown. The situation in Ukraine in relation to the state of the social development has been outlined and looked at.
\end{abstract}

Key words: Civilization transformations, social progress, evolution of scholars' attitude to socialization, quality of life standards, social partnership, socialization of social relations in Ukraine.

\section{INTRODUCTION}

\section{Formulation of the problem.}

The large-scale civilization transformations caused above all by the rapid development of scientific and technological progress since the end of the last century have touched all branches and spheres of social life of the countries and caused the change of place of a person with its needs for development. In today's economic environment, the social component of development has not simply evolved into an identical economic development component but has often begun to determine the latter. That is why theoretical studies of social processes in public life, its socialization, and mechanisms for achieving social agreement are relevant in our time.

\section{Analysis of recent research and publications.} field of view of theorists. In particular, various aspects of the general process of socialization have been fundamentally explored in the works of O. Belyaev [5], A. Galchinsky [2], V. Geyets [3], O. Golovinov [4], M. Khvesik [6], E. Shutayeva [8] and others.

Revised Version Manuscript Received on October 15, 2019.

Gumeniuk P. Yuriy, Doctor of Economic Science, Head of the International Tourism and hospitality Department, Ternopil National Economic University, Ukraine (Email: oohumenuk@gmail.com)

Gumeniuk O.Olena, Phd of Economic, vice Professor of Accounting and Economics of Legal Support Agro Industrial Business Department, Ternopil National Economic University, Ukraine (Email:

Huhul Y. Oksana, $\mathrm{PhD}$ in Economics, Associate Professor of the Department of International Tourism and Hotel Business, Ternopil National Economic University, Ukraine.(Email: OksanaGGG@i.ua)

Kolinets B. Lesya, Doctor of Economic Science, Professor of the International Economics' Department, Ternopil National Economic University, Ukraine

Olha Tsokol, PhD student of Production and Investment Management Department, National University of Life and Environmental Sciences of Ukraine, Kyiv, Ukraine; (Email: olyazokol@ukr.net)
Problems of socialization of social life are constantly in the oohumenuk@gmail.com)

The purpose of the article is to explore the socialization as a new challenge in current conditions. To achieve this goal it is necessary:

- to show general trends in the development of socialization processes;

- to substantiate the importance of developing social partnership mechanisms in today's context;

- to outline the current state of social relations socialization processes in Ukraine.

\section{RESULT AND DISCUSSION}

The formation of the concept of a socially oriented market economy is the result of the rapid expansion of socialization processes in all spheres of economic life since the first half of the last century. Already in the second half of the twentieth century it became clear that only a country which managed to combine market mechanisms with social mechanisms in the economic system could be successful and prosperous. At present, socialization of the economy has become one of the conditions for prosperity of the country, because all developed market systems of the present day (USA, European countries, and developed countries of Asia) necessarily have powerful social mechanisms.

It should be noted that in the works of leading Ukrainian theorists there is an approach to the socialization of the economy as a fundamental pattern of social development. In their view, socialization as such has been traced back to the moment of "the appearance of man on Earth", when "the joint production of tools and their purposeful application ... become the basis ... the emergence ... of the laws of social relations" [2, p.15].

At the same time, the process of penetration of socialization processes in the modern sense into the economy did not occur immediately. A.Galchinsky identifies several stages of the so-called "socialization of capitalism". [2, p. 178] At the first stage (from the Paris Commune to the beginning of the Great Depression in the United States), the processes of socialization of the economy are not yet systematic, although an understanding of their necessity is already coming. In the second stage (30 - 70-ies of the last century), models of socially oriented market systems with certain national characteristics are formed in the developed countries of the world, and the processes of socialization acquire mass systemic character. In the third contemporary stage the processes of socialization are often associated with the transition to a qualitatively new level - the transition to a 
post-industrial society, the construction of a knowledge economy.

From the outset, the concept of a social market economy has been advanced by scholars as the "third way" between the arbitrary, deliberately formed order, the market capitalism of most Western countries of the 19th - beginning of the 20th centuries, and the totalitarian planned economies of the so-called socialist countries. The effectiveness of market mechanisms, in general, was not called into question but it was noted that the market could lead to socially undesirable results and therefore needed restriction and regulation.

It should be noted that the concepts of socialization of the economy emerged in different interpretations within different economic schools. Thus, within the neoclassical direction, such basic concepts of socialization of the economy as the concept of social market economy (A. Müller-Armak, L. Erhard), the concept of human capital (G. Becker, T. Schultz), the concept of social order (F.F. Hayek). The neo-Keynesian trend led to the emergence of such concepts of socialization of the economy as the concept of mixed economy (J.Tinbergen, R.Slow, J.Gelbraith) and the concept of social well-being or "quality of life society" (K. Balduen, M.Lernep, E.Hansen, U Rostov) other concepts, among which there is the concept of the national economy proposed by S. Mocherny [1, p.36].

Noteworthy is the group of concepts of socialization of the economy of the second half of the twentieth century. According to this concept, the material side matters but not more than the cultural and intellectual development of the individual.

Secondly, the concept of basic needs according to which goods and services produced by the public sector, primarily health care, education and housing, as well as primary necessities, including food related to social was proposed to be basic. The concept was aimed at benefiting the poor within a limited set of human needs. However, this was the disadvantage of this overly minimalist concept. It envisaged, in its framework, "the expansion of labor-intensive industries, especially in countries where there is a surplus of labor resources in order to ensure GDP and population incomes, even at low levels of labor productivity," was further criticized by the proponents of socializing the economy by raising knowledge-intensive intellectual production with high level of value added in finished products.

The concept of expanding of human choice by A. Sen is also very interesting. According to it the well-being of people is judged not by the level of per capita income or other economic indicators but by the ability of people to live as they wish. Indicators are not material values but social activity, professional development, access to knowledge and other benefits of civilization with increased human needs. It is clear that only those with a high income can have all these benefits but income is no longer an end in itself but only a means to an end. There is an inversion: the goal now is knowledge and experience. Revenue is a tool to achieve this, not the other way around.

However, despite the differences in approaches and methodology, scholars from different economics schools and fields have agreed that market mechanisms need regulation, and the key feature of achieving social orientation of the

market system is the fulfillment of the state functions to support and develop the social sphere, create a system of social guarantees and protection of different sections of the population. Such regulatory influence on the part of the state is fully in line with the interests of the market and business. The state is responsible for maintaining competition, preventing crises, conflicts, shaping consumer demand, the system of government orders and so on. In social terms, the state develops and implements internal and external socio-economic policies, forms the legal bases of economy aimed at stable provision of high standards of living and employment of the population provides social protection, creates conditions for the effective development of the whole society.

At the same time, the social responsibility of economic entities of different forms of ownership, including those of the private sector of the country's economy, is that the purpose of their activity is gradually ceasing to be solely profit maximization, and now the satisfaction of social needs and interests of workers is decisive. That is, there is an awareness that the existence and development of a business is inseparable from the social environment in which the business operates. The main directions of ensuring such responsibility are the desire to provide the market with quality goods and services, creating the right working conditions for the able-bodied population, preserving the environment, setting wages at the labor cost level, paying taxes to social insurance funds.

In addition, in the new social conditions, there is a change in the qualitative characteristics of labor resources. The limited number of manpower, the dynamics of their age characteristics (the "aging of the nation"), and the increasing need for highly skilled workers have led to changes in the attitude of business to the employee. Previously, in industrial production, which was extensive, economic efficiency depended on the degree of exploitation of the workforce, which acted as a means of maximizing economic effect. At the present stage, the employee can no longer be considered as a means of maximizing profits, and investment in human resources development is not only necessary but also economically viable. The importance of state regulatory influence on the processes related to the reproduction of labor resources (on the demographic situation in the country, on the improvement of educational, qualification characteristics of labor resources, financial support of social events, etc.) has increased. In developed countries, the introduction of social mechanisms at different levels has created a powerful layer of the so-called middle class as the basis of a developed society.

Therefore, due to the long evolution of the development of socio-economic relations at all levels, the preconditions for creating a mechanism of so-called social partnership were created. Social partnership as such is a set of socio-economic relations between employees, business and the state, which are realized in their joint activity, and aimed at coordinating interests, finding compromises, avoiding or resolving conflicts between them. [5, p.224] Now, in the reproduction of the workforce, qualitatively new principles are laid, the 
antagonism that was previously characteristic of the relationship between the worker and the capitalist is completely overcome. The employee leases the means of production, assuming the role of employer of capital, as well as capital - the role of employer of labor. There are significant changes in the management system, overcoming the alienation of the employee from personal participation in management. Against the background of all these processes, there are significant transformations in the organization of labor; in particular, the production process is humanized, enriched with new content, intellectualized. [2, p.222]

With regard to the processes of socialization of social relations in Ukraine, the turbulence of recent years, which has affected all sectors of society, spheres and sectors of the economy, has affected the social sphere as well. During this period, the processes of socialization in Ukraine slowed down a bit, and the development of the middle class as the basis of a social consent society slowed down.

For five years there has been a decline in the standard of living of ordinary citizens, an increase in the unemployment rate, a rapid rise in inflation at a constant household income. Another severe economic blow for most Ukrainian citizens was the increase in tariffs for all utilities.

At the same time, the controversy in humanitarian issues deepened, in particular, the language issue became more acute, and the problems of displaced persons from the eastern regions and the Crimea remained unresolved. Unfortunately, it is not possible to overcome the military-political conflict in some areas of our country and to restore its territorial integrity. A negative phenomenon was also that Ukraine, which had previously become a donor region of educated and motivated pedagogical and scientific staff, is now rapidly becoming a provider of entrants to other countries in the world. The total number of students leaving for education abroad is estimated from 18 to 20 thousand annually to 30 thousand in total [7, p.277].

In such circumstances, it is difficult to talk about the implementation of certain quality of life standards and the like. However, as is well known, any economic crisis carries with it hidden opportunities for development. Ukraine's image in the world has significantly increased in recent years. It is now well known that Ukrainians want to live in a democratic society, strive to ensure the realization of European values, including social values, in domestic territories. Ukraine was indeed perceived as part of Europe.

In our opinion, the activation of socialization processes in Ukraine is possible through the introduction of mechanisms of social partnership at all levels, the consolidation of society, the search for certain compromises. Solving economic problems undoubtedly continues to be a key aspect of socialization, since it is practically impossible to reach social compromise in a context of general impoverishment.

\section{CONCLUSION}

Thus, the attention of theorists around the world has long been paid to the problem of the penetration of socialization in all spheres of life. There are different concepts of socialization of the economy, but the only one for all is the need to ensure social consent through the inhibition of negative economic impacts, the introduction of social protection and social guarantees. Social partnership mechanisms at all levels are being actively developed and implemented.

In Ukraine, the implementation of social mechanisms has been slowed down over a period of time due to a number of economic, humanitarian and political problems. It is now urgent to step up their action at all levels.

\section{REFERENCES}

1. Vahovych I.M. (2006) Sotsializatsiya ekonomiky yak peredumova formuvannia konceptsii stalogo rozvytku [Socialization of economy as background of the formation of the concept of the sustainable development].Zbirnik naukovyh prac. Lutsky derjavny technichniy universitet, vypusk 4, 33 - 54.[in Ukrainian].

2. Galchinsky A. (2006) Globalni transformacii: kontseptualni perspektivy. Metodologichny aspekti [Global transformations: conceptual perspectives. Methodological aspects].Naukove vydanna, 312. [in Ukrainian].

3. Geyets V. (2010) Dovira yak element sotsialnogo kapitalu $\mathrm{v}$ ekonomichnomu rozvitku Ukrainy [Trust as an component of the social capital in economic growth of Ukraine], Ekonomichna teoriya, 3, 7 - 19. [in Ukrainian].

4. Golovinov O. (2007) Sotsialno oriyentovana rynkova ekonomyka yak model sotsialnoyi dergavy [Socially oriented market economy as the model of the social country], Ekonomika i derjava, 2, 10 - 12. [in Ukrainian].

5. Belayev O., Nikolayev Y., Kelichaviy A. (2014) Sotsialna ekonomika [Social economy], navchlny posibnyk, KNEU, 481.

6. Khvesyk M., Golian V. (2007) Institucialna model pryrodokorystuvannia $\mathrm{v}$ umovah globalnih vyklikiv [Institutional model of the nature using in conditions of the global challenges], monografiya, 480. [in Ukrainian].

7. Shevchuk A. (2013) Motyvatsiyni mehanizmy regulyuvannia osvitnih migraciy: vtzniy i viyizniy aspecty [Motivational mechanismus of regulating of the educational migrations: entry and exit aspects], Sotsialno-ekonomichny problemy suchasnogo periodu Ukrainy, vypusk 3 (101), 277. Retrieved from http://ird.gov.ua/vid_3/sep20133(101)_275_ShevchukA. pdf. [in Ukrainian].

8. Shutayeva E. (2014) Sotsializaciya ekonomiky kak odna iz kluchevih sostavliayuschih mirovoy ekonomicheskoy transformacii [Socialization of economy as one of the key components of the world economic transformation], Ucheniye zapisky TNU im. V.I. Vernadskogo. Ekonomika i upravleniye, 27 (66), 1, 186 - 194. [in Russian].

9. Reznik, N.P., Demyan, Y.Y., Tokar, Y.I., Gupta, S.K., Ostapchuk, A.D. (2019): Mechanism of investment maintenance for the sustainable development of the agricultural sphere. International Journal of Engineering and Advanced Technology, 8 (11), pp. 112-116.

\section{AUTHORS PROFILE}

1. Gumeniuk P. Yuriy, Doctor of Economic Science, Head of the International Tourism and hospitality Department, Ternopil National Economic University

ORCID: https://orcid.org/0000-0001-8203-5749

yuhumeniuk64@gmail.com

tel: 38067-749-15-86

2. Gumeniuk O.Olena, Phd of Economic, vice Professor of Accounting and Economics of Legal Support Agro Industrial Business Department, Ternopil National Economic University 
ORCID: https://orcid.org/0000-0001-9806-2362

Web of Science Researcher ID

V-2399-2017

oohumenuk@gmail.com

tel: 38067-351-09-65

3. Huhul Y. Oksana, PhD in Economics, Associate Professor of the Department of International Tourism and Hotel Business, Ternopil National Economic University. ORCID: https://orcid.org/0000-0003-3052-5759, Web of Science Researcher ID I - 4021-2017,

tel:38067378 1715 , OksanaGGG@i.ua

4. Kolinets B. Lesya, Doctor of Economic Science, Professor of the International Economics' Department, Ternopil National Economic University

ORCID: https://orcid.org/0000-0002-7005-0519

Web of Science Researcher ID

H-5772-2017

5. Olha Tsokol, PhD student of Production and Investment Management Department, National University of Life and Environmental Sciences of Ukraine, Kyiv, Ukraine; olyazokol@ukr.net 